\title{
Kajian Pola Pemberian Pakan dan Sex yang Berbeda pada Ayam KUB
}

\author{
(Study of Feeding Patterns and a Different Sex in Chicken KUB)
}

\author{
Natalia $\mathrm{H}^{1}$, Budiyanto $\mathrm{F}^{1}$, Widiastuti $\mathrm{SN}^{2}$ \\ ${ }^{1}$ Balai Pembibitan Ternak Unggul dan Hijauan Pakan Ternak Sembawa \\ Jl. Peternakan, Lalang Sembawa, Sembawa, Banyu Asin, Sumatera Selatan 30953 \\ ${ }^{2}$ Balai Pengkajian Teknologi Pertanian Sumatera Selatan \\ Jl. Kol. H Barlian km 7, Sukarami, Kota Palembang, Sumatera Selatan 30961 \\ bptusbw@yahoo.com; hestysbw@yahoo.co.id
}

\begin{abstract}
A research to compare the effects of standard feed in BPTU-HPT Sembawa (P1) with a commercial feed that are familiar in society around Sembawa (P2) and also see the response of sex were fed standard in BPTU-HPT Sembawa (P1) to KUB Chicken. Different feeding was given only up to 4 weeks old chicken. Parameters measured were weight gain, feed conversion ratio (FCR) and costs spend to get FCR (cost per FCR) which ultimately feed the treatment known to most efficiently and effectively to increase the family income. The results showed between P1 and P2 feed treatment was no difference in weight gain, except weight four week old chickens. KUB chicken FCR age of 4, 6, 11 weeks who were given better P1 from P2. However, by the time the chicken was 13 weeks and 15 weeks, the resulting value is not significantly different. Based on cost per FCR, feed treatment provides value P2 smaller than P1. Treatment based on sex, it is known that male KUB chicken responds to body weight, and cost per FCR FCR were better than females KUB chicken. Based on this study concluded that the treatment of P2 feed and male KUB further increase family income.
\end{abstract}

Key Words: Chicken KUB, Sembawa, Weigh Gain, FCR

\begin{abstract}
ABSTRAK
Suatu penelitian dilakukan untuk membandingkan dampak pemberian pakan yang standar di BPTU-HPT Sembawa (P1) dengan pakan komersial yang familiar di masyarakat sekitar Sembawa (P2) dan juga melihat respon sex yang diberi pakan standar di BPTU-HPT Sembawa (P1) terhadap Ayam KUB. Pemberian pakan yang berbeda hanya pada umur 1-4 minggu. Parameter yang diukur yaitu berat badan, konversi pakan (FCR) dan biaya yang keluarkan untuk mendapatkan FCR yang pada akhirnya merujuk kepada pakan yang paling efisien dan efektif terhadap peningkatan pendapatan keluarga. Hasil penelitian menunjukan antara perlakuan pakan P1 dan P2 tidak ada perbedaan berat badan ayam KUB umur 6, 11, 13 dan 15 minggu kecuali pada berat badan ayam KUB umur empat minggu yang diberi pakan P1 lebih tinggi dibandingkan dengan ayam KUB yang diberi P2. FCR ayam KUB umur 4, 6, 11 minggu yang diberi P1 lebih baik dari P2 namun masuk umur 13 dan 15 minggu FCR nya tidak berbeda. Berdasarkan cost per FCR, perlakuan pakan P2 memberikan nilai yang lebih kecil dibandingkan dengan P1. Berdasarkan perlakuan sex, diketahui bahwa ayam KUB jantan memberikan respon terhadap berat badan, FCR dan cost per FCR yang lebih baik dibandingkan dengan ayam KUB betina. Berdasarkan penelitian ini dapat disimpulkan bahwa perlakuan pakan P2 dan ayam jantan KUB lebih meningkatkan pendapatan keluarga.
\end{abstract}

Kata Kunci: Ayam, KUB, Sembawa, Berat Badan, FCR

\section{PENDAHULUAN}

Menurut Iskandar (2006) peran ayam lokal terutama ayam kampung dalam ekonomi keluarga dan masyarakat masih cukup tinggi, terutama di pedesaan. Ayam kampung 
dipelihara masyarakat terutama untuk tabungan keluarga, yang bisa dijual sewaktu-waktu pada saat memerlukan uang tunai. Atas dasar itu, upaya penelitian terus dilakukan dalam rangka menemukan bibit ternak yang efektif dan efisien serta mampu meningkatkan pendapatan keluarga. Ayam KUB atau kampung Unggul Badan Litbang Pertanian merupakan salah satu terobosan dari hasil penelitian Balitnak Bogor yang telah melalui seleksi genetik dari beberapa ayam kampung pilihan. Informasi dari Direktorat Perbibitan Ternak (2015) ayam ini sudah dilepas sebagai galur dengan keputusan Menteri Pertanian Republik Indonesia 274/Kpts/SR.120/2/2014 dengan nama KUB-1.

BPTU-HPT Sembawa sebagai satu-satunya UPT Ditjen PKH yang bergerak dibidang pembibitan ayam diberi mandat untuk memelihara dan menyebarkan ayam KUB ke masyarakat. Menurut Gunawan (2005) ayam kampung, menempati populasi terbanyak di antara ayam-ayam lokal lain, menunjukkan bahwa ayam kampung mempunyai beberapa kelebihan yang diapresiasi masyarakat, sehingga eksistensinya dipertahankan. Kelebihan tersebut antara lain harga jual satuan produk lebih tinggi dibandingkan dengan ayam ras. Selain dari pada itu, pengembangan ayam lokal dapat mendukung program pelestarian dan pemanfaatan plasma nutfah dan memberikan kontribusi berarti pada pasokan daging dan telur nasional. Bahkan pada saat terjadi krisis moneter tahun 1998, usahatani ayam lokal lebih mampu bertahan dibandingkan dengan usahatani ayam ras. Menurut Julianto (2016) pemulia ayam kampung Balai Penelitian Peternakan, Ciawi, menyatakan, keunggulan yang paling menonjol dari ayam KUB adalah rasa daging ayam yang enak dan produktifitas telurnya lebih tinggi. Komposisi kimiawi daging ayam KUB yang dipotong pada umur 10 minggu yakni, kadar air 73,41\%, protein $24,55 \%$, lemak $1,83 \%$ dan kolesterol $0,14 \%$. Meski sudah bisa panen pada umur 10-12 minggu, sifat dan tekstur daging ayamnya tetap seperti ayam kampung.

Seiring dengan perkembangannya, lalu muncul pemikiran bagaimana ketika bibit ayam KUB ini dipelihara oleh masyarakat dengan kemampuan yang terbatas, termasuk keterbatasan kemampuan menyediakan pakan bagi ayam yang kualitasnya sama dengan yang biasa diberi pada saat di BPTU-HPT Sembawa. Selain itu, diperlukan juga kajian sejauh mana efisiensi pejantan KUB dibanding betinanya didalam merespon pakan yang sama. Untuk itu dilakukan pengujian dengan melihat sejauh mana perkembangan atau respon ayam KUB ini dengan manajemen pola pemberian pakan yang dipakai di BPTUHPT Sembawa yang kemudian kita bandingkan dengan pakan yang berbeda serta dengan sex berbeda yang mendapat perlakuan pakan yang sama. Secara khusus pengujian manajemen pola pemberian pakan ini hanya diberikan perlakuan yang berbeda dari umur 1-4 minggu saja mengingat umur ini adalah umur yang dianggap riskan dan mempengaruhi perkembangan ayam berikutnya.

Tujuan penelitian ini melihat sejauh mana efisiensi dan efektivitas ayam KUB yang diberi perlakuan pakan berbeda dari umur 1-4 minggu dan juga mengetahui perbedaan respon sex jantan betina terhadap pola pemberian pakan yang ada di BPTU-HPT Sembawa.

\section{MATERI DAN METODE}

Penelitian ini menggunakan 575 ekor DOC ayam KUB yang terdiri dari 500 ekor betina dan 75 ekor pejantan. DOC dipelihara di kandang ayam BPTU-HPT Sembawa selama tiga bulan. DOC dikelompokkan menjadi dua kelompok perlakuan pakan yang berbeda pada umur 1-4 minggu, seterusnya pakan yang sama, meliputi:

1. Perlakuan 1 (P1) menggunakan 250 ekor DOC betina dan 75 ekor DOC jantan dengan 3 perlakuan pakan ransum standar BPTU-HPT yaitu umur 1-4 minggu menggunakan BR- 
1 dengan PK 21\%, umur 5-8 minggu menggunakan BR-2 dengan PK 19\% dan umur 915 minggu menggunakan BR-3 dengan PK $17 \%$.

2. Perlakuan 2 (P2) menggunakan 250 ekor DOC betina dengan 3 perlakuan pakan yaitu umur 1-4 minggu menggunakan pakan konsentrat komersial yang biasa dibeli masyarakat sekitar sembawa dengan PK 21-23\%, sedangkan umur 5-8 minggu menggunakan BR-2 dengan PK 19\% dan umur 9-15 minggu menggunakan BR-3 dengan PK $17 \%$.

Kedua perlakuan pakan diatas hanya membandingkan kelompok ayam betina. Untuk perlakuan perbedaan sex hanya diterapkan Perlakuan 1. Alasannya, karena penelitian menyesuaikan dengan program pemeliharaan ayam di BPTU-HPT Sembawa.

Pemberian ransum dua kali dalam sehari dengan jumlah ransum pada minggu pertama adalah 7,5 g/ekor/hari. Setiap minggu jumlahnya ditambah 7,5 g/ekor/hari sampai umur 12 minggu jumlah yang diberikan adalah 90 g/ekor/hari. Selanjutnya, sampai umur 15 minggu diberikan 90 g/ekor/hari. Harga pakan BR1 (P1) adalah Rp. 7.500/kg dan pakan yang biasa dibeli masyarakat sekitar Sembawa (P2) Rp. 4.300/kg. Penimbangan bobot hidup dilakukan pada minggu ke 4, 6, 11, 13 dan 15. Setelah penimbangan semua ayam, selanjutnya diberi makan dan air minum yang sudah ditambahkan vitamin $\mathrm{C}$ untuk mengurangi stres yang terjadi akibat proses secara acak.

Data dianalisis menggunakan program SPSS, metode pengujian pakan dengan Rancangan Acak Lengkap (RAL) pola searah menguji dua perlakuan pakan dan tiga ulangan. Perlakuan sex pada ayam KUB diuji terpisah hanya pada penggunaan pakan P1. Jika hasil analisis memberikan perbedaan yang nyata antar perlakuan, maka dilanjutkan dengan uji Duncan's New Multiple Range Test (DMRT).

\section{HASIL DAN PEMBAHASAN}

\section{Pertambahan berat badan (PBB)}

Berdasarkan Tabel 1 diketahui bahwa pada saat ayam betina berumur 6, 11, 13 dan 15 minggu antara kedua perlakuan pakan tidak ada perbedaan signifikan. Respon perlakuan terhadap bobot badan hanya berbeda nyata pada saat ayam berumur empat minggu. Bobot badan ayam P1 11,5\% lebih berat daripada P2. Bahkan nilai kedua perlakuan ini lebih baik dibandingkan dengan yang dilaporkan Iskandar (2006) bahwa bobot ayam kampung umur empat minggu adalah $148 \mathrm{~g}$.

Tabel 1. Respon pola pemberian pakan dan sex terhadap pertambahan berat badan

\begin{tabular}{lccccc}
\hline \hline \multirow{2}{*}{$\begin{array}{l}\text { Umur } \\
\text { (minggu })\end{array}$} & \multicolumn{3}{c}{ Respon perlakuan terhadap berat badan $(\mathrm{g})$} \\
\cline { 2 - 3 } & \multicolumn{2}{c}{ Perlakuan pakan } & & \multicolumn{2}{c}{ Perlakuan sex dengan pakan P1 } \\
\cline { 2 - 3 } \cline { 5 - 6 } & P1 & $207,76 \pm 36,88^{\mathrm{b}}$ & & $278,27 \pm 31,34^{\mathrm{a}}$ & $231,60 \pm 26,26^{\mathrm{b}}$ \\
\hline 4 & $231,60 \pm 26,26^{\mathrm{a}}$ & & & Jantan & Betina \\
6 & $373,68 \pm 52,45^{\mathrm{a}}$ & $351,28 \pm 49,46^{\mathrm{a}}$ & & $450,53 \pm 59,48^{\mathrm{a}}$ & $373,68 \pm 52,45^{\mathrm{b}}$ \\
11 & $920,68 \pm 103,23^{\mathrm{a}}$ & $842,12 \pm 120,52^{\mathrm{a}}$ & & $1088,00 \pm 118,02^{\mathrm{a}}$ & $920,68 \pm 103,23^{\mathrm{b}}$ \\
13 & $1097,68 \pm 90,14^{\mathrm{a}}$ & $1055,36 \pm 101,67^{\mathrm{a}}$ & & $1316,67 \pm 100,90^{\mathrm{a}}$ & $1097,68 \pm 90,14^{\mathrm{b}}$ \\
15 & $1234,44 \pm 118,44^{\mathrm{a}}$ & $1261,88 \pm 125,77^{\mathrm{a}}$ & & $1727,33 \pm 169,71^{\mathrm{a}}$ & $1234,44 \pm 118,44^{\mathrm{b}}$ \\
\hline
\end{tabular}

Superskrip huruf yang berbeda pada baris yang sama untuk setiap jenis perlakuan menunjukkan perbedaan nyata $(\mathrm{P}<0,05)$ 
Namun yang menarik pada umur 13 minggu terlihat bahwa kedua perlakuan pakan sama-sama baru menghasilkan berat badan ekonomis yaitu $\mathrm{P} 1=1097,68 \pm 90,12 \mathrm{~g}$ dan P2 $=$ $1055,36 \pm 101,67 \mathrm{~g}$, yang merupakan berat badan ayam siap jual yaitu berat badan di atas 1 kg. Hal ini menunjukan bahwa kandungan nutrisi kedua pakan tidak berbeda dampaknya terhadap pertambahan berat badan ayam KUB, meski kandungan nutrisi yang tertera pada karung pakan P2 lebih tinggi yaitu protein kasar (PK) 21-23\% dibandingkan dengan PK pakan P1 yaitu 21\%. Hal ini juga dimungkinkan karena memang perbedaan pakan yang sebenarnya diberikan hanya pada umur 1-4 minggu, selanjutnya pakan yang diberikan pada kedua perlakuan tersebut adalah sama.

Pada perlakuan sex yang berbeda terlihat sangat jelas menunjukkan konsistensi bahwa ayam jantan selalu memberi pertambahan berat badan yang jauh lebih tinggi dan berbeda nyata dibandingkan kelompok ayam betina. Hal ini sejalan dengan pendapat Mufti (2003), bahwa ayam kampung jantan memiliki tubuh lebih besar daripada ayam kampung betina. Postur tubuh jantan diakibatkan hormon testoteron. Menurut Soeparno (1992), testosteron sebagai steroid dari androgen yang mengakibatkan pertumbuhan ternak jantan lebih cepat dibandingkan dengan pertumbuhan ternak betina.

Pada umur 11 minggu, ayam betina dengan dua perlakuan pakan yang berbeda belum mencapai berat $1 \mathrm{~kg}$ dan non-signifikan diantara kedua pakan tersebut yaitu $\mathrm{P} 1=$ $920,68 \pm 103,23 \mathrm{~g}$ dan $\mathrm{P} 2=842,12 \pm 120,52 \mathrm{~g}$. Berbeda halnya dengan ayam pejantan yang beratnya sudah $1088,00 \pm 118,12 \mathrm{~g}$ dan signifikan berbeda dengan berat ayam betina $920,68 \pm 103,23 \mathrm{~g}$, walau pakannya sama. Namun, angka pertambahan berat badan jauh lebih baik dibandingkan dengan ayam kampung biasa yang dipelihara secara intensif. Menurut Resnawati \& Bintang (2005), pada umur 12 minggu ayam kampung yang dipelihara secara intensif mencapai berat 636,16 g untuk betina dan 1086,30 g untuk jantan.

Hasil penelitian menunjukkan bahwa ayam KUB umur 15 minggu yang dipelihara intensif memiliki berat yang cenderung lebih besar dibandingkan dengan ayam kampung dewasa yang dipelihara tradisional yaitu ayam KUB betina dengan perlakuan pakan P1 = $1.234,44 \mathrm{~g}$, ayam KUB betina dengan perlakuan pakan $\mathrm{P} 2=1.261,88 \mathrm{~g}$ dan ayam KUB jantan dengan perlakuan pakan P1 $=1.727,33 \mathrm{~g}$ karena menurut Rajab et al. (2012), berat badan ayam kampung jantan umur $>20$ minggu berkisar antara 1674,73-1742,62 g.

\section{Feed convertion ratio (FCR) dan cost per FCR (Rp)}

Berdasarkan perhitungan pada Tabel 2, dapat diketahui bahwa FCR ayam KUB yang mendapat pakan P1 umur 4, 6 dan 11 minggu lebih baik dibandingkan dengan ayam KUB yang diberi pakan P2. Hal ini menunjukan bahwa untuk menghasilkan bobot badan ayam KUB yang tidak berbeda nyata pada umur 6 dan 11 minggu dari P2, P1 membutuhkan pakan lebih sedikit dibandingkan dengan P2. Berbeda dengan umur empat minggu tampilan bobot badan yang berbeda nyata antara kedua perlakuan pakan menghasilkan FCR yang juga berbeda nyata.

Namun, pada umur 13 dan 15 minggu FCR yang ditunjukan dari kedua pola pakan diatas tidak berbeda nyata. Hal yang menarik adalah untuk mencapai berat ekonomis (berat di atas $1 \mathrm{~kg}$ ) yaitu pada umur 13 minggu terlihat bahwa FCR antara kedua perlakuan pakan tidak berbeda nyata. Berbeda halnya dengan kajian berdasarkan perlakuan sex dengan pakan P1 memberi efek nyata terhadap FCR yang dihasilkan. Hal ini seiring dengan berat badan yang dari awalpun berbeda nyata antara jantan dan betina. Jantan memberikan hasil terbaik yang tidak dapat dibantah baik dari capaian berat badan dan FCR dibandingkan dengan ayam KUB betina. 
Ayam KUB identik sebagai ayam kampung tipe pedaging dengan berat panen 1-1,5 kg dengan pangsa pasar rumah makan ayam bakar. Kajian mendalam menunjukkan meskipun pakan P1 memberikan FCR yang lebih baik pada ayam KUB, namun karena pakan yang diberikan berbeda harga tentu pada akhirnya memberikan hitungan keuntungan yang berbeda pula terlihat jelas bahwa ayam dengan pakan P2 memiliki cost per FCR yang lebih sedikit, cost yang kecil ini selain disebabkan perbedaan harga pakan P2 yang lebih rendah juga gabungan dari berat badan yang tidak berbeda antara kedua perlakuan.

Tabel 2. FCR perlakuan dan kebutuhan biaya (cost) per FCR

\begin{tabular}{|c|c|c|c|c|}
\hline & \multicolumn{2}{|c|}{ Perlakuan pakan } & \multicolumn{2}{|c|}{ Perlakuan sex dengan pakan $\mathrm{P} 1$} \\
\hline & $\mathrm{P} 1$ & $\mathrm{P} 2$ & Jantan & Betina \\
\hline Umur (minggu) & Feed convertion ratio & & & \\
\hline 4 & $* 2,27 \mathrm{a}$ & $2,53 b$ & $* 1,89 \mathrm{a}$ & $2,27 b$ \\
\hline 6 & $* 2,95 \mathrm{a}$ & $3,14 b$ & $* 2,45 \mathrm{a}$ & $2,95 b$ \\
\hline 11 & $* 3,76 \mathrm{a}$ & $4,11 b$ & $* 3,18 \mathrm{a}$ & $3,76 b$ \\
\hline 13 & $\mathrm{~ns} 4,30 \mathrm{a}$ & $4,48 \mathrm{a}$ & $* 3,59 \mathrm{a}$ & $4,30 \mathrm{~b}$ \\
\hline 15 & $\mathrm{~ns} 4,85 \mathrm{a}$ & $4,74 \mathrm{a}$ & $* 3,46 a$ & $4,85 \mathrm{~b}$ \\
\hline Umur (minggu) & Cost per FCR (Rp) & & & \\
\hline 4 & 17.479 & 15.534 & 14.553 & 17.479 \\
\hline 6 & 22.715 & 19.280 & 18.865 & 22.715 \\
\hline 11 & 28.952 & 25.235 & 24.486 & 28.952 \\
\hline 13 & 33.110 & 27.507 & 27.643 & 33.110 \\
\hline 15 & 37.345 & 29.104 & 26.642 & 37.345 \\
\hline
\end{tabular}

*Berbeda nyata $(\mathrm{P}<0,05),{ }^{\mathrm{a}-\mathrm{b}}$ Superskrip huruf yang berbeda pada baris yang sama menunjukkan

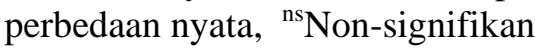

Pakan yang diasumsikan masyarakat terbaik dengan harga termahal yang ada di poultry shop di sekitar Sembawa (P1) ternyata memberikan pertambahan berat badan yang tidak berbeda nyata untuk jenis ayam KUB. Artinya bahwa potensi genetik ayam KUB sebagai ayam kampung sudah terpenuhi oleh pakan yang selama ini familiar di masyarakat sekitar sembawa (P2) dan justru tidak memberikan respon pertambahan bobot badan yang lebih tingi meski dengan pemberiaan pakan yang mahal sekalipun. Namun, mungkin berbeda jika diberikan kepada ayam ras yang memang secara potensi genetik memiliki kapasitas lebih unggul. Pada perlakuan pakan P2 mengeluarkan cost paling sedikit untuk semua umur maka tentunya keuntungan yang diperolehpun paling tinggi dengan asumsi biaya lainnya diabaikan karena sama untuk semua perlakuan. Hal ini menunjukkan bahwa ayam KUB jantan yang diberi pakan P2 direkomendasikan sebagai program untuk peningkatan pendapatan keluarga. Ini mengajarkan kepada kita bahwa bijak dalam berbudidaya ayam kampung adalah penting agar perolehan keuntungan maskimal.

\section{KESIMPULAN}

Penelitian di atas dapat ditarik kesimpulan bahwa ayam KUB jantan menghasilkan pertambahan bobot badan lebih tinggi daripada betina dan pemberian pakan P2 lebih baik untuk program peningkatan pendapatan keluarga. Hal ini memberikan gambaran bahwa 
ayam KUB yang diberi pakan komersial yang biasa dipakai masyarakat di sekitar Sembawa ternyata lebih mampu menghemat biaya. Beberapa saran yang dapat diberikan untuk pengembangan penelitian ini adalah perlu ada pengujian lebih lanjut efek pakan kontrol (P1) dan pakan pembanding (P2) terhadap reproduktivitas ternak dan kualitas penetasan terkait dengan potensi penghasil bibit.

\section{UCAPAN TERIMA KASIH}

Penulis mengucapkan puji syukur kepada Allah SWT atas segala rahmat dan karuniaNya. Terima kasih kepada Bapak Ir. Nugroho Budi Suprijatno, selaku kepala BPTU-HPT Sembawa atas dukungan dan semangatnya. Seluruh dukungan dari Bapak Yumoko Ginto, Bapak Arie Sutanto, Bapak Kori Karim, Ibu Delly Nista dan Bapak Syahrul, kami ucapkan terima kasih. Semua yang terlibat dalam penelitian ini: Sri Hindrawati, Ibu Ati Sihombing, Syahril, Cipta Ramdani, Hendra Kurniawan, Human, Sumirah, Eka Yuliani, Pari, Rinda, Agus, Rinda, Wied, Nining dan semua karyawan BPTU-HPT Sembawa yang tidak bisa disebutkan satu persatu, kami ucapkan terima kasih atas dedikasinya dalam penelitian ini.

\section{DAFTAR PUSTAKA}

Direktorat Perbibitan Ternak. 2015. Penetapan dan pelepasan rumpun atau galur ternak Indonesia tahun 2014-2015. Jakarta (Indoensia): Kementerian Pertanian.

Gunawan. 2005. Evaluasi model pengembangan ayam buras di Indonesia: Kasus di Jawa Timur. Dalam: Subandriyo, Diwyanto K, Inounu I, Setiadi B, Zainuddin D, Priyanti A, Handiwirawan E, penyunting. Prosiding Lokakarya Nasional Inovasi Teknologi Pengembangan Ayam Lokal. Semarang, 26 Agustus 2005. Bogor (Indonesia): Puslitbangnak dan Fakultas Peternakan, Universitas Diponegoro. hlm. 260-271.

Iskandar S. 2006. Strategi pengembangan ayam lokal.Wartazoa. 16:190-197.

Julianto. 2016. Ayam KUB alternatif beternak ayam kampung [Internet]. [cited 13 Feb 2017]. Available from: http://tabloidsinartani.com/content/read/ayam-kub-alternatif-beternak-ayamkampung/

Mufti R. 2003. Studi ukuran dan bentuk tubuh ayam kampung, ayam Pelung dan persilangannya [Skripsi]. [Bogor (Indonesia)]: Institut Pertanian Bogor.

Rajab, Bercomin J, Papilaya. 2012. Sifat kuantitatif ayam kampung lokal pada pemeliharaan tradisional. Agrinimal. 2:61-64.

Resnawati H, Bintang IAK. 2005. Produktivitas ayam lokal yang dipelihara secara intensif. Dalam: Subandriyo, Diwyanto K, Inounu I, Setiadi B, Zainuddin D, Priyanti A, Handiwirawan E, penyunting. Prosiding Lokakarya Nasional Inovasi Teknologi Pengembangan Ayam Lokal. Semarang, 26 Agustus 2005. Bogor (Indonesia): Puslitbangnak dan Fakultas Peternakan, Universitas Diponegoro. hlm. 121-126.

Soeparno. 1992. Ilmu dan teknologi daging. Yogyakarta (Indonesia): Gadjah Mada University Press. 